\title{
Distribution Pattern of Hepatitis C Virus Genotypes and Correlation with Viral Load and Risk Factors in Chronic Positive Patients
}

\author{
Arnolfo Petruzziello ${ }^{a}$ Nicola Coppola ${ }^{b}$ Giovanna Loquercio ${ }^{a}$ \\ Samantha Marigliano a Margherita Giordano a Rosa Azzaro a \\ Anna Maria Diodato ${ }^{a}$ Vincenzo lervolino $^{a}$ Gaetano Di Costanzo ${ }^{a}$ \\ Catia Addolorata Di Macchia ${ }^{a}$ Tommaso Di Meo a Laurenza Paradiso b \\ Rosario Ferro $^{c}$ Pasquale Giuliano $^{c}$ Ferdinando Russo $^{c}$ Giuseppe Pasquale ${ }^{b}$ \\ Carmela Cacciapuoti ${ }^{a}$ \\ a Laboratory of Virology and Molecular Biology 'V. Tridente', Transfusion Service, Department of Haemathology, \\ Istituto Nazionale Tumori - Fondazione 'G. Pascale', IRCCS Italia, and 'b Department of Mental Health and Public \\ Medicine, Section of Infectious Diseases, SUN Second University of Naples, 'ASL NA2 Nord Public Health Company, \\ Sanitary District 43, Casoria, Naples, Italy
}

\section{Key Words}

Chronic hepatitis · Polymerase chain reaction $\cdot \mathrm{HCV}$

genotyping $\cdot$ Infected carriers $\cdot$ Hepatocellular carcinoma

\begin{abstract}
Objective: Hepatitis $\mathrm{C}$ virus (HCV) has emerged as a leading cause of chronic hepatitis, liver cirrhosis and hepatocellular carcinoma worldwide. The purpose of this study was to describe the distribution pattern of HCV genotypes in chronic hepatitis patients in the Campania region of southern Italy and estimate their association with risk factors and viral load. Materials and Methods: 404 consecutive HCV ribonucleic acid-positive patients were included in the study. HCV genotyping was carried out by the HCV line probe assay test and viral load estimation by the TaqMan real-time PCR system. Results: The predominant genotype was 1 (63.6\%), followed by genotype $2(29.4 \%), 3(6.2 \%)$ and $4(0.8 \%)$. Subtype $1 \mathrm{~b}$ was more frequent in females than in males. Conversely, genotype 3 was more frequent in males. No significant difference was observed in age distribution of HCV genotypes. Surgery and dental therapy were the most frequent risk factors for
\end{abstract}

\section{KARGER}

E-Mail karger@karger.com

www.karger.com/int genotype 1 and intravenous drug abuse and tattooing for genotype 3. Patients with genotype 1 more frequently showed high HCV viral load when compared to those with genotypes 2 and 3. Conclusion: The present study revealed that HCV genotypes 1 and 2 accounted for over $95 \%$ of all $\mathrm{HCV}$ infections in the Campania region, and genotype 1 was more frequently associated with a higher viral load when compared to genotypes 2 and 3 .

(c) 2014 S. Karger AG, Basel

\section{Introduction}

Hepatitis $\mathrm{C}$ virus (HCV) is one of the leading causes of end-stage liver disease with high progression to cirrhosis and hepatocellular carcinoma [1-5]. Although many attempts to identify the natural history and progression of HCV infection have been made, several aspects are still unclear, even though cofactors such as alcohol intake, age, gender, genotype/subtype, viral load and mode of infection seem to play an important role in the progression of liver disease [6-8]. The knowledge of genotypes in
Dr. Arnolfo Petruzziello

Istituto Nazionale Tumori - Fondazione 'G. Pascale'

Via Mariano Semmola

IT-80131 Napoli (Italy)

E-Mail a.petruzziello@istitutotumori.na.it 
chronic hepatitis $\mathrm{C}$ seems also crucial to identify those patients who need more aggressive therapeutic management. In fact, genotypes 1 and 4 show more resistance as compared to genotypes 2 and 3 to pegylated-interferon (PEG-IFN) and ribavirin combination therapy and thus require different treatment duration and dose [9-12].

In the last two decades some studies have shown that viral load can be considered an important prognostic indicator of response to antiviral therapy and that a high pretreatment viral load can be linked with low rates of response to therapy [13-18]. Patients infected with HCV genotype 1 but with a low baseline HCV ribonucleic acid (RNA) content $\left(<2.0 \times 10^{5} \mathrm{IU} / \mathrm{ml}\right)$ are more likely to achieve a sustained virological response than those with an intermediate $\left(2.0 \times 10^{5}-6.0 \times 10^{5} \mathrm{IU} / \mathrm{ml}\right)$ or high $(>6.0$ $\times 10^{5} \mathrm{IU} / \mathrm{ml}$ ) viral load when treated with PEG-IFN and ribavirin for 24 weeks [19-22]. Moreover, recently, a single nucleotide polymorphism on chromosome 19, upstream of the interleukin-28B (IL28-B) gene, has been reported as strongly associated with the spontaneous clearance of HCV $[23,24]$ or induced by PEG-IFN + ribavirin treatment [25-27], primarily among individuals infected with genotype 1 .

The purpose of this study was to describe the distribution of HCV genotypes in chronic hepatitis patients from the Campania region in southern Italy, and to estimate their association with risk factors and viral load.

\section{Materials and Methods}

\section{Study Population and Sample Collection}

From a total of 947 anti-HCV-positive patients, consecutively recruited among patients referred to ambulatories of virology of the National Cancer Institute 'Fondazione G. Pascale', IRCCS Italia and of the Second University of Naples SUN, Section of Infectious Diseases, Naples, Italy, between January 2012 and April 2013, we included 475 anti-HCV/HCV RNA-positive patients (50.1\%), all coming from different cities/towns of the Campania region. All the remaining 472 patients (49.8\%) were HCV-RNA-negative and therefore were excluded from the study.

The ethics committee reviewed the study which was conducted following the principles of the ICH GCP and Declaration of Helsinki. All subjects provided written informed consent. All data was de-identified during data collection.

All patients with a chronic HCV infection (anti-HCV- and HCV-RNA-positive for at least 6 months) were included in the study; they were naive for antiviral therapy at the enrollment. Of the 475 enrolled patients, 83 (17.4\%) were HCV carriers with persistently normal alanine-aminotransferase serum values (PNALT) and $392(82.6 \%)$ had a history of steadily abnormal serum ALT values. According to the Italian guidelines [28], the definition of an anti-HCV carrier with PNALT serum values applies to a subject with at least 9 consecutive ALT normal values observed at 2-month- ly intervals over an 18-month observation period, while the definition of chronic hepatitis $C$ to a subject with abnormal ALT values in absence of other causes. A complete history with possible route of infection and standard biochemical liver function tests were collected.

All patients enrolled were asymptomatic, negative for anti$\mathrm{HIV}, \mathrm{HBsAg}$ and anti-HDV and had no clinical or serological signs of other chronic liver disease (autoimmune disease, non-alcoholic steatohepatitis, hemochromatosis, etc.). No patient admitted alcohol abuse that was defined as the consumption of alcohol exceeding $30 \mathrm{~g} / \mathrm{day}$ for females and $40 \mathrm{~g} /$ day for males in the last 6 months.

Liver biopsy was performed in 330 (69.5\%) of the enrolled patients. It was proposed to all the 392 patients with abnormal ALT and performed in 311, but was refused in 52 cases or contraindicated in 29, showing in all cases a liver biopsy-based diagnosis of chronic hepatitis. Of the 83 patients with PNALT serum values the liver biopsy was proposed only to the 27 patients aged from 50 to 65 years with genotype 1 and performed in 19 of these.

Liver specimens were fixed in formalin, embedded in paraffin and stained with hematoxylin-eosin and Masson's trichrome stain. In each case, the liver specimens were $>2 \mathrm{~cm}$ in length and had more than 11 portal tracts. Liver biopsies were examined by a pathologist (G.P.) who, unaware of the clinical and laboratory data, used the Ishak scoring system to grade necroinflammation and fibrosis [29] and a home-made scoring system for steatosis that he had been using for decades (score $1=1-10 \%$ of hepatocytes with fatty deposition, score $2=11-30 \%$; score $3=31-60 \%$; score $4=$ $>60 \%$ ) [8]. Considering the 330 patients with liver biopsy, the histological activity index mean $(+\mathrm{SD})$ was $6.04+3.5$, the fibrosis 2.39 +1.44 , and steatosis scores $1.21+1.26$.

In $71(14.9 \%)$ of the 475 enrolled subjects, serum was insufficient for viral genotyping and HCV RNA quantification. 404 patients were therefore included in this study of which 195 (48.3\%) were males and $209(51.7 \%)$ females. The mean age of female patients was 62.5 years (range 25-87), and that of males was 61.0 years (range 28-80). Data on risk factors for HCV were available for the majority of included patients (357/404). In case of more than one risk factor the one most likely to have caused infection was assigned. No difference in gender, age, distribution of risk factors and liver disease was found between the 404 patients included in the study group and the 71 excluded.

\section{Serology and Molecular Analysis}

All the plasma samples were analyzed for the presence of antiHCV antibodies by means of the Vitros enhanced chemiluminescent immunoassay (ECi) test (Ortho Clinical Diagnostics), used according to the manufacturer's instructions. This test employs chemiluminescent technology and results are reported as signalto-cutoff (S/Co). Results $\geq 1.00$ were considered reactive for $\mathrm{HCV}$ antibodies. Specificity and sensitivity of the test were 99.97 and $100 \%$, respectively.

As previously described [30] and following CDC recommendations [31], anti-HCV-positive samples with $S / C o$ ratios of $\geq 8.0$ can be reported as positive without further supplemental testing. We therefore decided to include in this study only repeatedly anti$\mathrm{HCV}$-reactive samples with $\mathrm{S} / \mathrm{Co}$ ratios of $\geq 8.0$. These samples were subsequently tested for the presence of HCV RNA and its quantification was performed via COBAS AmpliPrep/TaqMan HCV 48 (Roche Diagnostics System, Inc.), which exploits a polymerase chain reaction in real time (RT-PCR). Linear range of 
Fig. 1. Genotype-specific probes adsorbed

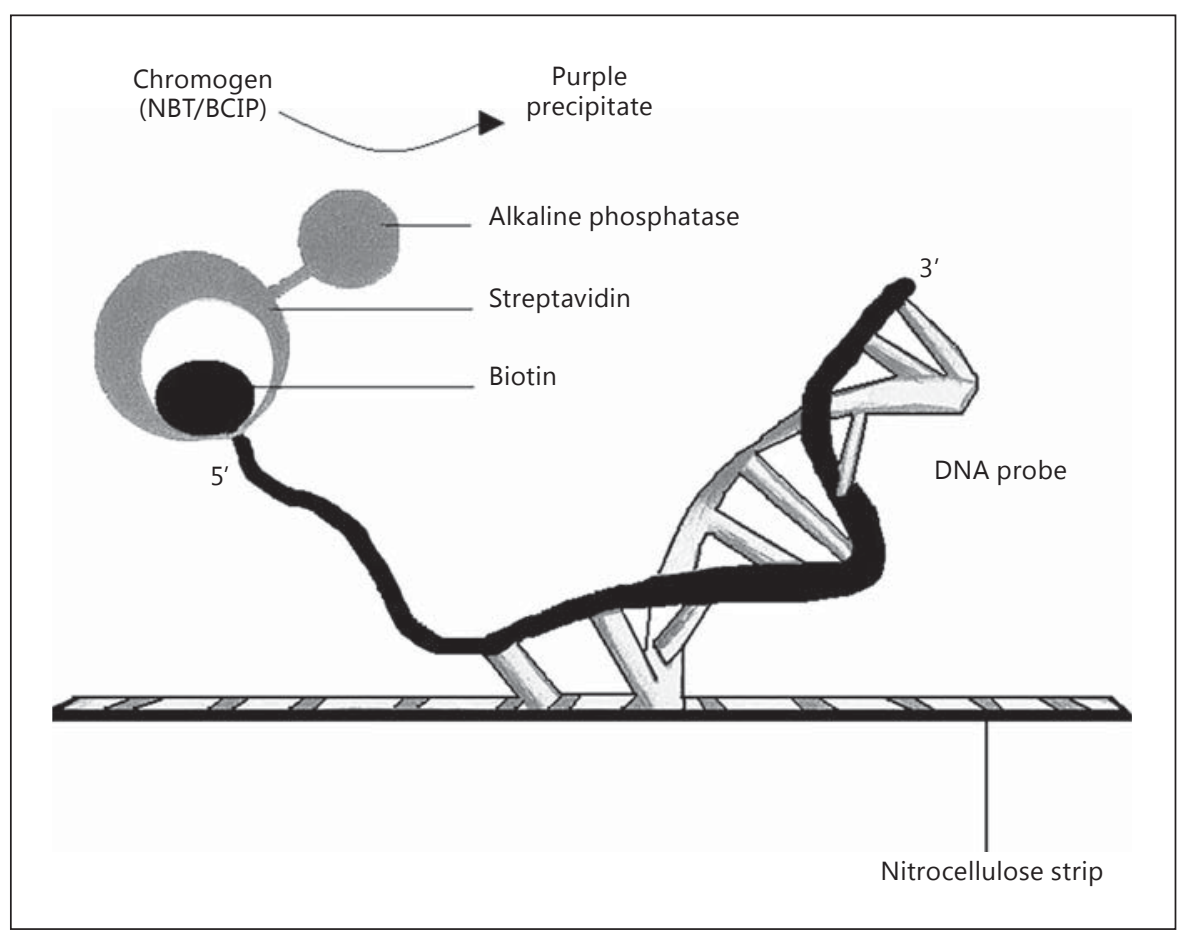
onto nitrocellulose strips.

quantification of the test was $1.50 \mathrm{E}+01$ to $6.90 \mathrm{E}+07 \mathrm{HCV}$ RNA $\mathrm{IU} / \mathrm{ml}$, using the accuracy acceptance criterion of $\pm 0.3 \log ^{10}$. Specificity of the test was $100 \%$ and its detection limit was $15 \mathrm{IU} / \mathrm{ml}$.

HCV genotyping was performed using the Versant HCV Genotype Assay 2.0 line probe assay (LiPA) test (Siemens Healthcare Diagnostics), which involves the amplification and hybridization of viral genome fragments, the latter by means of genotype-specific probes adsorbed onto nitrocellulose strips (fig. 1). The various steps were performed by Auto-LiPA, a fully automated system for complete genotyping. Specificity and sensitivity of this test are 96 and $99.4 \%$, respectively, and its detection limit is $15 \mathrm{IU} / \mathrm{ml}$.

The limitations of the test INNOLiPA are well known, especially concerning its inability to correctly discriminate the subtypes $2 \mathrm{a}$ and $2 \mathrm{c}$ of the genotype 2 and subtype $1 \mathrm{c}$ of genotype 1 , as demonstrated using a restriction fragment length polymorphism (RFLP) analysis [32]. Anyway, its degree of specificity is similar to that of RFLP analysis and, as previously reported, comparable to that of the direct sequencing test Trugene, with an accuracy of 76 and $74 \%$, respectively, even though the INNOLiPA confirms its less subtype discriminating power in subtyping genotype $2[33$, 34].

\section{Statistical Analysis}

Statistical analysis of the data was performed using SPSS for Windows, version 16. The data are presented as mean and SD and categorical variables in absolute number and percentage. Frequency tables were analyzed using the $\chi^{2}$ tests with the Pearson correlations being used to assess the significance of the correlation between the categorical variables. Differences in the mean ages in the genotypes and subtypes were analyzed using Student's t test. In all tests, $\mathrm{p}$ values $<0.05$ were regarded as statistically significant.

\section{Results}

Table 1 shows the distribution of HCV genotypes in the studied population. The predominant genotype was 1 (63.6\%), followed by genotypes 2 (29.4\%), $3(6.2 \%)$ and 4 $(0.8 \%)$. No genotypes 5 and 6 were detected. No statistical difference was observed in the gender distribution considering the overall genotypes 1 and 2 (61.6 vs. $65.5 \%$ for genotype 1 and 27.7 vs. $31.1 \%$ for genotype 2), even though subtype $1 \mathrm{~b}$ was predominant among females (56.4 vs. $44.7 \%, \mathrm{p}<0.05$ ). Conversely, genotype 3 was more frequent in males than in females (9.7 vs. $2.9 \%, \mathrm{p}<$ $0.005)$, possibly due to a higher prevalence of intravenous drug addiction among men.

In order to compare the prevalence of HCV genotypes according to age, patients were categorized into three age groups. As shown in table 2, no significant difference was observed with regard to the number of patients with $\mathrm{HCV}$ genotype 1 in different age groups (64.6\% of 177 subjects who were older than 60 years vs. $62.5 \%$ of 227 who were younger than 60 years). The HCV genotype 2 was more common in the over 60-year age group than in the 60-year and under age group: $34.8 \%$ of 177 subjects who were older than 60 years versus $25.1 \%$ of 227 who were younger than 60 years. However, all these differences were not significant for the statistical analysis. In contrast, genotype 3 
Table 1. Gender distribution of HCV genotypes

\begin{tabular}{|c|c|c|c|c|c|c|}
\hline & \multicolumn{2}{|c|}{ Frequency } & \multicolumn{4}{|c|}{ Gender } \\
\hline & \multirow[t]{2}{*}{$\mathrm{n}$} & \multirow[t]{2}{*}{$\%$} & \multicolumn{2}{|c|}{ male } & \multicolumn{2}{|c|}{ female } \\
\hline & & & $\mathrm{n}$ & $\%$ & $\mathrm{n}$ & $\%$ \\
\hline Genotype 1 & 257 & 63.6 & 120 & 61.6 & 137 & 65.5 \\
\hline $1 a$ & 22 & 5.5 & 17 & 8.8 & 5 & 2.4 \\
\hline $1 b$ & 205 & 50.7 & 87 & $44.7^{\mathrm{A}}$ & 118 & $56.4^{\mathrm{B}}$ \\
\hline $1 c$ & 1 & 0.2 & 1 & 0.5 & 0 & 0.0 \\
\hline $1^{*}$ & 29 & 7.2 & 15 & 7.6 & 14 & 6.7 \\
\hline Genotype 2 & 119 & 29.4 & 54 & 27.7 & 65 & 31.1 \\
\hline $2 a / 2 c$ & 69 & 17.1 & 32 & 16.5 & 37 & 17.7 \\
\hline $2 \mathrm{a}$ & 10 & 2.5 & 2 & 1.0 & 8 & 3.8 \\
\hline $2 b$ & 4 & 1.0 & 4 & 2.0 & 0 & 0.0 \\
\hline $2 c$ & 1 & 0.2 & 0 & 0.0 & 1 & 0.5 \\
\hline $2 a / 2 b$ & 1 & 0.2 & 1 & 0.5 & 0 & 0.0 \\
\hline $2^{*}$ & 34 & 8.4 & 15 & 7.7 & 19 & 9.1 \\
\hline Genotype 3 & 25 & 6.2 & 19 & $9.7^{\mathrm{C}}$ & 6 & $2.9^{\mathrm{D}}$ \\
\hline $3 a$ & 19 & 4.7 & 14 & 7.1 & 5 & 2.4 \\
\hline 3 & 6 & 1.5 & 5 & 2.6 & 1 & 0.5 \\
\hline Genotype 4 & 3 & 0.8 & 2 & 1.0 & 1 & 0.5 \\
\hline $4 a$ & 1 & 0.3 & 1 & 0.5 & 0 & 0.0 \\
\hline $4 c / 4 d$ & 2 & 0.5 & 1 & 0.5 & 1 & 0.5 \\
\hline Total & 404 & 100.0 & 195 & 48.3 & 209 & 51.7 \\
\hline $\begin{array}{r}\text { Differenc } \\
\mathrm{p}<0.05 ;{ }^{\mathrm{C}} \mathrm{vs} \\
* \text { Other } \mathrm{c}\end{array}$ & $\begin{array}{l}\text { sig } \\
, \mathrm{p}<\end{array}$ & $\begin{array}{l}\text { ant } t \\
05 \text {. }\end{array}$ & he & stical & sis: & vs. ${ }^{B}$ \\
\hline
\end{tabular}

was more frequently observed in younger patients: $19.5 \%$ of the 42 patients who were under 35 years versus $4.7 \%$ of 362 who were over 35 years for genotype $3, p<0.0005$. The same data were observed for genotype 4 ( $1.3 \%$ of the 227 younger patients vs. none of the 177 older ones).

The possible routes of infection were determined by detailed questionnaire. The distribution of risk factors versus genotypes in the 404 studied patients is reported in table 3. Dental therapy was the most frequent risk factor for HCV acquisition in genotype 1 (30.7 vs. $16.8 \%$ in genotype $2, \mathrm{p}<0.005)$, whereas intravenous drug abuse and tattooing were prevalent in genotype $3(60.0 \%$ of the 25 patients with genotype 3 vs. $8.2 \%$ of the 376 patients with genotype 1 or genotype $2, \mathrm{p}<0.0001$ ). Surgery was more frequently identified as a prevalent risk factor in the patients with genotype $2(42.0 \%)$ than in those with genotype $1(33.8 \%)$, but with no significance at the statistical analysis. Statistical analysis showed that risk factors were independent of gender (data not shown).
Table 2. Age distribution of HCV genotypes

\begin{tabular}{|c|c|c|c|c|c|c|}
\hline & \multicolumn{2}{|c|}{$>60$ years } & \multicolumn{2}{|c|}{$35-60$ years } & \multicolumn{2}{|c|}{$<35$ years } \\
\hline & $\mathrm{n}$ & $\%$ & $\mathrm{n}$ & $\%$ & $\mathrm{n}$ & $\%$ \\
\hline Genotype 1 & 115 & 64.6 & 119 & 64.3 & 23 & 56.1 \\
\hline $1 \mathrm{a}$ & 3 & 1.7 & 17 & 10.0 & 2 & 0.0 \\
\hline $1 b$ & 94 & 52.8 & 92 & 50.0 & 19 & 4.5 \\
\hline $1 c$ & 0 & 0.0 & 0 & 0.0 & 1 & 0.0 \\
\hline $1^{*}$ & 18 & 10.1 & 10 & 5.0 & 1 & 0.0 \\
\hline Genotype 2 & 62 & 34.8 & 46 & 24.9 & 11 & 26.8 \\
\hline $2 a / 2 c$ & 43 & 24.0 & 21 & 11.3 & 5 & 12.2 \\
\hline $2 \mathrm{a}$ & 1 & 0.6 & 8 & 4.4 & 1 & 2.4 \\
\hline $2 b$ & 1 & 0.6 & 2 & 1.0 & 1 & 2.4 \\
\hline $2 c$ & 0 & 0.0 & 1 & 0.6 & 0 & 0.0 \\
\hline $2 a / 2 b$ & 1 & 0.6 & 0 & 0.0 & 0 & 0.0 \\
\hline $2^{*}$ & 16 & 9.0 & 14 & 7.6 & 4 & 9.8 \\
\hline Genotype 3 & 0 & $0.0^{\mathrm{A}}$ & 17 & $9.2^{\mathrm{B}}$ & 8 & $19.5^{\mathrm{C}}$ \\
\hline $3 \mathrm{a}$ & 0 & 0.0 & 11 & 5.9 & 7 & 17.1 \\
\hline 3 & 0 & 0.0 & 6 & 3.3 & 1 & 2.4 \\
\hline Genotype 4 & 0 & 0.0 & 3 & 1.6 & 0 & 0.0 \\
\hline $4 \mathrm{a}$ & 0 & 0.0 & 1 & 0.6 & 0 & 0.0 \\
\hline $4 \mathrm{c} / 4 \mathrm{~d}$ & 0 & 0.0 & 2 & 1.0 & 0 & 0.5 \\
\hline Total & 177 & 43.8 & 185 & 45.8 & 42 & 10.4 \\
\hline
\end{tabular}

Differences significant to the statistical analysis: ${ }^{A}+{ }^{B}$ vs. ${ }^{C}, p<$ 0.0005 . ${ }^{*}$ Other cases not further subclassified;.

According to Jensen et al. [15], viral load was classified into three categories based on its levels such as low $(<2.0$ $\left.\times 10^{5} \mathrm{IU} / \mathrm{ml}\right)$, intermediate $\left(2.0 \times 10^{5}-6.0 \times 10^{5} \mathrm{IU} / \mathrm{ml}\right)$ and high $\left(>6.0 \times 10^{5} \mathrm{IU} / \mathrm{ml}\right)$. The quantification was carried out in all 404 HCV RNA-positive patients and compared between the four groups of genotypes. RNA viral load shows a significant difference in magnitude among them $\left(5.03 \times 10^{6} \mathrm{IU} / \mathrm{ml}\right.$ in genotype 1 and $4.16 \times 10^{6} \mathrm{IU} /$ $\mathrm{ml}$ in genotype 2 vs. $1.70 \times 10^{5} \mathrm{IU} / \mathrm{ml}$ in genotype 3$)$. As shown in table 4 , the majority of patients infected with HCV genotype $1(242 / 257,94.2 \%)$ and genotype 2 $(107 / 119,89.9 \%)$ had a high or intermediate viral load $\left(\geq 2.0 \times 10^{5}\right)$ when compared to those infected with genotype $3(10 / 25,40.0 \%)$ and genotype $4(1 / 3,33.3 \%)$. Patients with genotype 1 more frequently had high $\mathrm{HCV}$ viral load than those with genotype 2 (78.3 vs. $65.5 \%$, p < $0.01)$. Moreover, the majority of patients infected with HCV genotype $3(15 / 25,60.0 \%)$ and genotype $4(2 / 3$, $66.6 \%$ ) showed a low viral load (table 4). No significant difference was observed between male and female infected patients (data not shown). 
Table 3. Route of transmission for HCV infection by genotypes

\begin{tabular}{|c|c|c|c|c|c|c|c|c|c|c|}
\hline \multirow[t]{2}{*}{ Route of transmission* } & \multicolumn{2}{|c|}{ Genotype 1} & \multicolumn{2}{|c|}{ Genotype 2} & \multicolumn{2}{|c|}{ Genotype 3} & \multicolumn{2}{|c|}{ Genotype 4} & \multicolumn{2}{|c|}{ Total } \\
\hline & $\mathrm{n}$ & $\%$ & $\mathrm{n}$ & $\%$ & $\mathrm{n}$ & $\%$ & $\mathrm{n}$ & $\%$ & $\mathrm{n}$ & $\%$ \\
\hline Surgery & 87 & 33.8 & 50 & 42.0 & 5 & 20.0 & 2 & 66.7 & 144 & 35.6 \\
\hline Dental therapy & 79 & $30.7^{\mathrm{A}}$ & 20 & $16.8^{\mathrm{B}}$ & 0 & 0.0 & 0 & 0.0 & 99 & 24.5 \\
\hline Intravenous drug use & 23 & $8.9^{\mathrm{C}}$ & 7 & $5.9^{\mathrm{D}}$ & $14^{\mathrm{E}}$ & 56.0 & 0 & 0.0 & 44 & 10.9 \\
\hline Blood transfusion & 22 & 8.6 & 8 & 6.7 & 3 & 12.0 & 0 & 0.0 & 33 & 8.2 \\
\hline Sexual exposure & 8 & 3.1 & 2 & 1.7 & 1 & 4.0 & 1 & 33.3 & 12 & 3.0 \\
\hline Needle stick injuries & 5 & 1.9 & 4 & 3.4 & 0 & 0.0 & 0 & 0.0 & 9 & 2.2 \\
\hline Piercing/tattoo & 0 & 0.0 & 1 & 0.8 & 1 & 4.0 & 0 & 0.0 & 2 & 0.5 \\
\hline Others & 9 & 3.5 & 5 & 4.2 & 0 & 0.0 & 0 & 0.0 & 14 & 3.5 \\
\hline Unknown & 24 & 9.3 & 22 & 18.5 & 1 & 4.0 & 0 & 0.0 & 47 & 11.6 \\
\hline Total & 257 & 100.0 & 119 & 100.0 & 25 & 100.0 & 3 & 100.0 & 404 & 100.0 \\
\hline
\end{tabular}

Differences significant to the statistical analysis: ${ }^{A}$ vs. ${ }^{\mathrm{B}}, \mathrm{p}<0.005 ;{ }^{\mathrm{C}}$ vs. ${ }^{\mathrm{E}}, \mathrm{p}<0.00001$; $^{\mathrm{D}}$ vs. ${ }^{\mathrm{E}}, \mathrm{p}<0.00001$.

* In case of more than one risk factor, the one most likely to have caused the infection was assigned.

Table 4. HCV viral load and its distribution in genotypes

\begin{tabular}{|c|c|c|c|c|c|c|}
\hline & \multicolumn{2}{|c|}{$<2.0+10^{5} \mathrm{IU} / \mathrm{ml}$} & \multicolumn{2}{|c|}{$2.0+10^{5}-6.0+10^{5} \mathrm{IU} / \mathrm{ml}$} & \multicolumn{2}{|c|}{$>6.0+10^{5} \mathrm{IU} / \mathrm{ml}$} \\
\hline & $\mathrm{n}$ & $\%$ & $\mathrm{n}$ & $\%$ & $\mathrm{n}$ & $\%$ \\
\hline Genotype 1 & 15 & 5.8 & 41 & $15.9^{\mathrm{C}}$ & 201 & $78.3^{\mathrm{A}}$ \\
\hline $1 \mathrm{a}$ & 0 & 0.0 & 5 & 1.9 & 16 & 6.2 \\
\hline $1 b$ & 12 & 4.6 & 32 & 12.5 & 162 & 63.0 \\
\hline $1 c$ & 0 & 0.0 & 0 & 0.0 & 1 & 0.4 \\
\hline $1 \mathrm{a} / 1 \mathrm{~b}$ & 0 & 0.0 & 0 & 0.0 & 1 & 0.4 \\
\hline $1^{*}$ & 3 & 1.2 & 4 & 1.5 & 21 & 8.3 \\
\hline Genotype 2 & 12 & 10.1 & 29 & $24.4^{\mathrm{D}}$ & 78 & $65.5^{\mathrm{B}}$ \\
\hline $2 \mathrm{a} / 2 \mathrm{c}$ & 10 & 8.5 & 16 & 13.5 & 43 & 36.1 \\
\hline $2 \mathrm{a}$ & 1 & 0.8 & 3 & 2.5 & 6 & 5.0 \\
\hline $2 b$ & 0 & 0.0 & 0 & 0.0 & 4 & 3.4 \\
\hline $2 c$ & 0 & 0.0 & 1 & 0.8 & 0 & 0.0 \\
\hline $2 a / 2 b$ & 0 & 0.0 & 0 & 0.0 & 1 & 0.8 \\
\hline $2^{*}$ & 1 & 0.8 & 9 & 7.6 & 24 & 20.2 \\
\hline Genotype 3 & 15 & 60.0 & 5 & 20.0 & 5 & 20.0 \\
\hline $3 a$ & 11 & 44.0 & 3 & 12.0 & 4 & 16.0 \\
\hline 3 & 4 & 16.0 & 2 & 8.0 & 1 & 4.0 \\
\hline Genotype 4 & 2 & 66.7 & 0 & 0.0 & 1 & 33.3 \\
\hline $4 a$ & 0 & 0.0 & 0 & 0.0 & 1 & 33.3 \\
\hline $4 c / 4 d$ & 2 & 66.7 & 0 & 0.0 & 0 & 0.0 \\
\hline
\end{tabular}




\section{Discussion}

HCV genotypes are widely distributed throughout the world and their distribution varies according to the geographical region [35, 36]. Genotypes 1 and 2 are mainly found in Europe and North America, with the exception of some endemic strains found in West Africa [37, 38], whereas the other genotypes are relatively restricted to certain geographic regions of Africa and the Middle East [39-42], with a particular prevalence of genotype 6 in some south-east Asian countries like Hong Kong and Vietnam $[43,44]$. However, no region has yet been found to contain high levels of HCV genotype 5 genetic diversity [45]. In Italy, around half of the cases are $1 \mathrm{~b}$ type, with $2 \mathrm{a} / 2 \mathrm{c}$ being the next prevalent subtype. The incidence of genotype $3 \mathrm{a}$ appears to be increasing and certainly merits investigations [46, 47].

Our results clearly showed that genotype $1 \mathrm{~b}$, as we described previously $[48,49]$, is historically the most prevalent throughout Italy and still remains so in our region $(50.7 \%)$ followed by genotype $2 \mathrm{a} / 2 \mathrm{c}(17.1 \%)$. These data seem to confirm what was observed by Rendina et al. [50] in a group of $252 \mathrm{HCV}$-infected patients also living in Campania. Genotypes 1a and 3, on the other hand, are considerably less common (5.5 and 6.2\%, respectively) when compared to the findings from studies performed in other regions of Italy (9.3 and $12.7 \%$, respectively) [51] and to the data observed by Rendina et al. [50] (50 and $23.08 \%$, respectively) in a group of 134 consecutive HIV/ $\mathrm{HCV}$ patients living in the same region.

The exact classification of the 'not further classified' genotype $1\left(1^{*}\right)$, which some studies group together with subtype $1 \mathrm{a}$, is still unclear. Instead, genotype 4 results are very rare in our population $(0.8 \%)$. Subtype $1 \mathrm{~b}$ was more frequent in females than in males. Conversely, genotype 3 was more frequent in males.

Considering the age-group distribution, contrary to what has previously been reported in the literature in the last two decades [52], genotypes $1 \mathrm{~b}$ and 2 (including subtype $2 \mathrm{a} / 2 \mathrm{c}$ and non-subtypable genotype 2 ) in our study do not show any significant difference between older patients and younger ones. These data seem to confirm what we previously described observing that the prevalence of patients with genotypes $1 \mathrm{~b}$ and 2 aged over 50 years was higher in the period 2006-2009 than 2009-2011 [49]. This finding appears to confirm the reduced risk of transfusion-related transmission over the years and in the meantime highlights the increasing role of no age-related risk factors in diffusion of $\mathrm{HCV}$ infection. Indeed, data analysis for finding an association of HCV genotypes with a possible route of transmission indicates dental therapy as one of the leading causes of $\mathrm{HCV}$ transmission in genotype 1 and surgery in genotype 2, while drug abuse seems to be the predominant risk factor associated with genotype 3 as previously described [50].

As reported before, we also observed a substantial correlation between the highest viral load and HCV genotype $1[53,54]$, whereas genotype 3 seems to be correlated to low levels of HCV replication. Since it has already been reported that patients with a higher viral load show lower response rates by standard antiviral therapy when compared to patients having a lower viral load $[54,55]$ and that the probability of a relapse after cessation of therapy is higher in patients with high HCV RNA levels prior to therapy [56], these data could indicate RNA viral load as a valuable predictive marker for the outcome of antiviral therapy.

A more and more increasing early diagnosis and treatment, especially among patients with genotypes 1 and 2, will probably be the future for prevention and health programs to control chronic HCV infection.

\section{Acknowledgements}

We gratefully acknowledge the technical assistance of Antonio Mattiello, Pasquale Barra, Gennaro Cozzolino, Giovanni Piscopo and Pasquale Moccia.

\section{Disclosure Statement}

The authors have no conflicts of interest to disclose.

References

-1 Seeff LB, Hollinger FB, Alter HJ, Wright EC Cain CM, Buskell ZJ, Ishak KG, et al: Longterm mortality and morbidity of transfusionassociated non- $A$, non- $B$, and type $C$ hepatitis: A National Heart, Lung, and Blood Institute collaborative study. Hepatology 2001;33: 455-463.

-2 Poynard T, Ratziu V, Benhamou Y, Opolon P, Cacoub P, Bedossa P: Natural history of HCV infection. Baillieres Best Pract Res Clin Gastroenterol 2000;14:211-228.

-3 Sagnelli E, Stroffolini T, Mele A, Almasio P, Coppola N, Ferrigno L, Scolastico C, et al: The importance of HCV on the burden of chronic liver disease in Italy: a multicenter prevalence study of 9,997 cases. J Med Virol 2005;75:522527. 
-4 Sagnelli E, Sagnelli C, Pisaturo MA, Coppola N, Pasquale G, Piccinino F: SIMIT Group: Liver biopsy in chronic hepatitis C: the experience of 15 Italian wards of infectious diseases. Infez Med 2012;20:31-36.

5 Alberti A, Vario A, Ferrari A, Pistis R: Review article: chronic hepatitis $\mathrm{C}$ - natural history and cofactors. Aliment Pharmacol Ther 2005; 22(suppl 2):74-78.

6 Lauer GM, Walker BD: Hepatitis C virus infection. N Engl J Med 2001;345:41-52.

7 Sagnelli E, Pisaturo M, Stanzione M, Messina V, Alessio L, Sagnelli C, Starace M: Clinical presentation, outcome, and response to therapy among patients with acute exacerbation of chronic hepatitis C. Clin Gastroenterol Hepatol 2013;11:1174-1180.

$\checkmark 8$ Zampino R, Coppola N, Cirillo G, Boemio A, Pisaturo M, Marrone A, Macera M, et al: Abdominal fat interacts with PNPLA3 I148M, but not with the APOC 3 variant in the pathogenesis of liver steatosis in chronic hepatitis C. J Viral Hepat 2013;20:517-523.

-9 Roffi L, Redaelli A, Colloredo G, Minola E, Donada C, Picciotto A, Riboli P, et al: Outcome of liver disease in a large cohort of histologically proven chronic hepatitis C: influence of HCV genotype. Eur J Gastroenterol Hepatol 2001;13:501-506.

10 Nguyen MH, Keeffe EB: Prevalence and treatment of hepatitis $C$ virus genotypes 4,5 , and 6. Clin Gastroenterol Hepatol 2005;3(suppl 2):S97-S101.

11 Coppola N, Pisaturo M, Tonziello G, Sagnelli C, Sagnelli E, Angelillo IF: Efficacy of pegylated interferon $a-2 a$ and $a-2 b$ in patients with genotype 1 chronic hepatitis C: a meta-analysis. BMC Infect Dis 2012;12:357.

$\checkmark 12$ Hnatyszyn $\mathrm{HJ}$ : Chronic hepatitis $\mathrm{C}$ and genotyping: the clinical significance of determining HCV genotypes. Antivir Ther 2005; 10 : $1-11$.

13 Bell H, Hellum K, Harthug S, Maeland A, Ritland S, Myrvang B, von der Lippe B, et al: Genotype, viral load and age as independent predictors of treatment outcome of interferon$a_{2 a}$ treatment in patients with chronic hepatitis C. Construct group. Scand J Infect Dis 1997;29:17-22.

14 Martinot-Peignoux M, Marcellin P, Pouteau M, Castelnau C, Boyer N, Poliquin M, Degott $\mathrm{C}$, et al: Pretreatment serum hepatitis $\mathrm{C}$ virus RNA levels and hepatitis $C$ virus genotype are the main and independent prognostic factors of sustained response to interferon- $\alpha$ therapy in chronic hepatitis C. Hepatology 1995;22: 1050-1056.

15 Jensen DM, Morgan TR, Marcellin P, Pockros PJ, Reddy KR, Hadziyannis SJ, Ferenci P, et al: Early identification of HCV genotype 1 patients responding to 24 weeks peginterferon$a^{2 a}(40 \mathrm{kDa}) /$ ribavirin therapy. Hepatology 2006;43:954-960.

16 Hadziyannis SJ, Sette H Jr, Morgan TR, Balan V, Diago M, Marcellin P, Ramadori G, et al: Peginterferon- $\alpha_{2 \mathrm{a}}$ and ribavirin combination therapy in chronic hepatitis $\mathrm{C}$ : a randomized study of treatment duration and ribavirin dose. Ann Intern Med 2004;140:346-355.

17 Dalgard O, Bjøro K, Hellum KB, Myrvang B, Ritland S, Skaug K, Raknerud N, et al: Treatment with pegylated interferon and ribavarin in HCV infection with genotype 2 or 3 for 14 weeks: a pilot study. Hepatology 2004;40: 1260-1265.

18 Chakravarti A, Ashraf A, Malik S: A study of changing trends of prevalence and genotypic distribution of hepatitis $C$ virus among high risk groups in North India. Indian J Med Microbiol 2013;31:354-359.

19 Chevaliez S, Pawlotsky JM: Interferon-based therapy of hepatitis C. Adv Drug Deliv Rev 2007;59:1222-1241.

20 Ahmad W, Ijaz B, Javed FT, Jahan S, Shahid I, Khan FM, Hassan S: HCV genotype distribution and possible transmission risks in $\mathrm{La}$ hore, Pakistan. World J Gastroenterol 2010; 16:4321-4328.

21 Fanning L, Kenny E, Sheehan M, Cannon B, Whelton M, O'Connell J, Collins JK, et al: Viral load and clinicopathological features of chronic hepatitis C (1b) in a homogeneous patient population. Hepatology 1999;29:904-907.

22 Strader DB, Wright T, Thomas DL, Seeff LB: American Association for the Study of Liver Diseases: Diagnosis, management, and treatment of hepatitis C. Hepatology 2004;39: 1147-1171.

23 Thomas DL, Thio CL, Martin MP, Qi Y, Ge $\mathrm{D}$, O'Huigin C, et al: Genetic variation in IL28B and spontaneous clearance of hepatitis C virus. Nature 2009;461:798-801.

24 Coppola N, Marrone A, Pisaturo M, Starace M, Signoriello G, Gentile I, Adinolfi LE, Sagnelli E, Zampino R: Role of interleukin$28 \mathrm{~B}$ in the spontaneous and treatment-related clearance of HCV infection in patients with chronic HBV/HCV dual infection. Eur J Clin Microbiol Infect Dis 2014:33:559-567.

25 Ge D, Fellay J, Thompson AJ, Simon JS, Shianna KV, Urban TJ, et al: Genetic variation in IL28B predicts hepatitis $C$ treatment-induced viral clearance. Nature 2009;461:399-401.

26 Tanaka Y, Nishida N, Sugiyama M, Kurosaki M, Matsuura K, Sakamoto N, et al: Genomewide association of IL28B with response to pegylated interferon- $\alpha$ and RBV therapy for chronic hepatitis C. Nat Genet 2009;41:11051109.

27 Coppola N, Pisaturo M, Sagnelli C, Sagnelli E, Angelillo IF: Peg-interferon plus ribavirin with or without boceprevir or telaprevir for HCV genotype 1: a meta-analysis on the role of response predictors. PLoS One 2014;9: e94542.

28 Prati D, Gasbarrini A, Mazzotta F, for AISF, SIMAST and SIMIT: Practice guidelines for the treatment of hepatitis $\mathrm{C}$ : recommendations from an AISF/SIMIT/SIMAST Expert Opinion Meeting. Dig Liver Dis 2010;42:81-91.

29 Ishak K, Baptista A, Bianchi L, Callea F, De Groote J, Gudat F, Denk H, et al: Histological grading and staging of chronic hepatitis. J Hepatol 1995;22:696-699.
30 Petruzziello A, Coppola N, Fraulo M, Loquercio G, Azzaro R, Diodato AM, Iervolino V, Di Costanzo G, Di Macchia CA, Di Meo T, Ferro R, Giuliano P, Pasquale G, Cacciapuoti C: Ortho Vitros ${ }^{\circledR}$-enhanced chemiluminescence assay for the detection of hepatitis $C$ virus antibodies. Determination of a 'borderline' range. AJMR 2013;7:2359-2364.

31 Centers for Disease Control and Prevention: Guideline for laboratory testing and result reporting of antibody to hepatitis $\mathrm{C}$ virus (antiHCV). MMWR Recomm Rep 2003;52:1-13.

- 32 Buoro S, Pizzighella S, Boschetto R, Pellizzari L, Cusan M, Bonaguro R, Mengoli C, Caudai $\mathrm{C}$, Padula $\mathrm{M}$, Valensin PE, Palù G: Typing of hepatitis $\mathrm{C}$ virus by a new method based on restriction fragment length polymorphism. Intervirology 1999;42:1-8.

33 Stuyver L, Wyseur A, Van Arnhem W, Lunel F, Laurent-Puig P, Pawlotsky JM, Kleter B, Bassit L, Nkengasong J, Van Doorn LJ: Hepatitis $C$ virus genotyping by means of 59-UR/ core line probe assay and molecular analysis of untypeable samples. Virus Res 1995;38: 137-157.

34 Halfon P, Trimoulet P, Bourliere M, Khiri H, De Ledinghen V, Couzigou P, Feryb JM, Alcaraz P, Renou C, Fleury HJA, Ouzan B: Hepatitis $C$ virus genotyping based on $5^{\prime}$ noncoding sequence analysis $\left(\right.$ Trugene $\left.^{\circledR}\right)$. J Clin Microb 2001;39:1771-1773.

35 Dusheiko G, Schmilovitz-Weiss H, Brown D, McOmish F, Yap PL, Sherlock S, McIntyre N, et al: Hepatitis $\mathrm{C}$ virus genotypes: an investigation of type-specific differences in geographic origin and disease. Hepatology 1994; 19:13-18.

-36 Zarkesh-Esfahani SH, Kardi MT, Edalati M Hepatitis $\mathrm{C}$ virus genotype frequency in Isfahan province of Iran: a descriptive cross-sectional study. Virol J 2010;24:69.

-37 Candotti D, Temple J, Sarkodie F, Allain J: Frequent recovery and broad genotype 2 diversity characterize hepatitis $C$ virus infection in Ghana, West Africa. J Virol 2003;77:79147923.

38 Jeannel D, Fretz C, Traore Y, Kohdjo N, Bigot A, Gamj EP, Jourdan G, Kourouma K, Maertenz G, Fumoux F, Fournel J, Stuyver L: Evidence for high genetic diversity and longterm endemicity of hepatitis $\mathrm{C}$ virus genotypes 1 and 2 in West Africa. J Med Virol 1998;55:92-97.

39 Mellor J, Holmes EC, Jarvis LM, Yap PL, Simmonds P: Investigation of the pattern of hepatitis $\mathrm{C}$ virus sequence diversity in different geographical regions: implications for virus classification. J Gen Virol 1995;76:24932507.

40 Ndjomou J, Pybus OG, Matz B: Phylogenetic analysis of hepatitis $C$ virus isolates indicates a unique pattern of endemic infection in Cameroon. J Gen Virol 2003;84:2333-2341.

41 Takahashi M, Yamada G, Miyamoto R, Doi T, Endo H, Tsuji T: Natural course of chronic hepatitis C. Am J Gastroenterol 1993;88:240243. 
42 Rivas-Estilla AM, Cordero-Pérez P, TrujilloMurillo Kdel C, Ramos-Jiménez J, ChenLópez C, Garza-Rodríguez Mde L, RamírezGutiérrez A: Genotyping of hepatitis $C$ virus in infected patients from Northeast Mexico. Ann Hepatol 2008; 7:144-147.

- 43 Sievert W, Altraif I, Razavi HA, Abdo A, Ahmed EA, Alomair A, Amarapurkar D, Chem $\mathrm{CH}$, Dou X, et al: A systematic review of hepatitis C virus epidemiology in Asia, Australia and Egypt. Liver Int 2011;31(suppl 2):61-80.

-44 Lu L, Li C, Fu Y, Gao F, Pybus OG, Abe K, Okamoto H, Hagedorn $\mathrm{CH}$, Murphy D: Complete genomes of hepatitis $\mathrm{C}$ virus (HCV) subtypes $6 \mathrm{c}, 6 \mathrm{l}, 6 \mathrm{o}, 6 \mathrm{p}$ and $6 \mathrm{q}$ : completion of a full panel of genomes for HCV genotype 6 . J Gen Virol 2007;88:1519-1525.

45 Verbeeck J, Maes P, Lemey P, Pybus OG, Wollants E, Song E, Nevens F, Fevery J, Delport W, Van Der Merwe S, Van Ranst M: Investigating the origin and spread of hepatitis C virus genotype 5a. J Virol 2006;80:42204226.

46 Ansaldi F, Bruzzone B, Salmaso S, Rota MC, Durando P, Gasparini R, Icardi G: Different seroprevalence and molecular epidemiology patterns of hepatitis $C$ virus infection in Italy. J Med Virol 2005;76:327-332.
47 Dal Molin G, Ansaldi F, Biagi C, D’Agaro P, Comar M, Crocè L, Tiribelli C, et al: Changing molecular epidemiology of hepatitis $\mathrm{C}$ virus infection in Northeast Italy. J Med Virol 2002; 68:352-356.

48 Sagnelli E, Coppola N, Scolastico C, Mogavero AR, Filippini P, Piccinino F: HCV genotype and 'silent' HBV coinfection: two main risk factors for a more severe liver disease. J Med Virol 2001;64:350-355.

49 Petruzziello A, Coppola N, Diodato AM, Iervolino V, Azzaro R, Di Costanzo G, Di Macchia CA, et al: Age and gender distribution of hepatitis $\mathrm{C}$ virus genotypes in the metropoli$\tan$ area of Naples. Intervirology 2013;56: 206-312.

50 Rendina D, Vigorita E, Bonavolta R, D'Onofrio M, Lura A, Pietronigro MT, Laccetti R, Bonadies G, Liuzzi G, Borgia G, Formisano P, Laccetti P, Portella G: HCV and GBV-c/HGV infection in HIV positive patients in southern Italy. Eur J Epidemiol 2001; 17:801-807.

51 Cenci M, Massi M, Alderisio M, De Soccio G, Recchia O: Prevalence of hepatitis $\mathrm{C}$ virus $(\mathrm{HCV})$ genotypes and increase of type 4 in Central Italy: an update and report of a new method of HCV genotyping. Anticancer Res 2007;27:1219-1222.
52 Guadagnino V, Stroffolini T, Rapicetta M, Costantino A, Kondili LA, Menniti-Ippolito F, Caroleo B, et al: Prevalence, risk factors, and genotype distribution of hepatitis $\mathrm{C}$ virus infection in the general population: a community-based survey in southern Italy. Hepatology 1997;26:1006-1011.

53 Jimenez-Mendez R, Uribe-Salas F, LópezGuillen P, Cisneros-Garza L, Castañeda-Hernandez G: Distribution of HCV genotypes and HCV RNA viral load in different regions of Mexico. Ann Hepatol 2010;9:33-39.

54 Burguete-García AI, Conde-González CJ, Jiménez-Méndez R, Juárez-Díaz $\mathrm{Y}$, MedaMonzón E, Torres-Poveda K, Madrid-Marina $\mathrm{V}$, et al: Hepatitis C seroprevalence and correlation between viral load and viral genotype among primary care clients in Mexico. Salud Publica Mex 2011;53(suppl 1):S7-S12.

55 Chakravarti A, Dogra G, Verma V, Srivastava AP: Distribution pattern of HCV genotypes and its association with viral load. Indian J Med Res 2011;133:326-331.

56 Adinolfi LE, Utili R, Andreana A, Tripodi MF, Marracino M, Gambardella M, Giordano $M$, et al: Serum HCV RNA levels correlate with histological liver damage and concur with steatosis in progression of chronic hepatitis C. Dig Dis Sci 2001;46:1677-1683. 